\title{
PEMANFAATAN PUPUK CAIR LIMBAH SAYUR DAN BUAH PADA KACANG TANAH (Arachis hypogea L.) DI DATARAN RENDAH KOTA PALOPO
}

\section{The increased of growth and yield of peanut plants (Arachis hypogea L.) through the application of liquid fertilizer prepared from fruit and vegetable waste in Lowland of Palopo City}

\author{
Nining Triani Thamrin*, Rahman Hairuddin, dan Eka Sudartik \\ Program studi Agroteknologi, Fakultas Pertanian, Universitas Cokroaminoto Palopo, Palopo, Indonesia \\ Doi: 10.37195/jac.v1i2.78
}

\section{*KORESPONDENSI \\ Telepon: +62-852-9859-9342 \\ E-mail: niningtriani1606@gmail.com \\ JEJAK PENGIRIMAN}

Diterima: 15 Jul 2019

Revisi Akhir: 22 Agu 2019

Disetujui: 31 Agu 2019

\section{KEYWORDS}

Peanut plants, Liquid fertilizer, Fruit waste, Vegetable waste

\section{KATA KUNCI}

Tanaman kacang tanah, Pupuk cair, Limbah buah, Limbah sayur

\begin{abstract}
This study aims to determine the effect and concentration of liquid fertilizer prepared from fruit and vegetable waste on the growth and yield of peanut plants. This research was carried out in the Experimental Field of the Faculty of Agriculture, University of Cokroaminoto Palopo, Jalan Lamaranginang, Batupasi Village, Wara Utara District, Palopo City. The experimental method used was a randomized block design (RBD) consisting of 5 treatments and 4 replications to comprise 20 experimental units. Each experimental unit consisted of 2 plant units so that there were 40 plant samples. The parameters observed were plant height, flowering age, root length, pod weight and the number of seeds. The results showed that the application of liquid fertilizer prepared from fruit and vegetable waste had a significant effect on the growth and yield of peanut plants. The effective concentration of fruit and vegetable waste liquid fertilizer was P4 (250 $m L . L^{-1}$ water) that produced the best plant height with an average value of $20.93 \mathrm{~cm}$, the average age of flowering was 33 days, the average root length was $4.49 \mathrm{~cm}$, and the best average pods (22.77 grams), while a concentration of $200 \mathrm{~mL} . \mathrm{L}^{-1}$ water (P3) produced the best average number of seeds (340.25 seeds).
\end{abstract}

Penelitian ini bertujuan untuk mengetahui pengaruh dan konsentrasi pupuk cair berbahan dasar limbah buah dan sayur terhadap pertumbuhan dan hasil tanaman kacang tanah. Penelitian ini dilaksanakan di Lahan Percobaan Fakultas Pertanian Universitas Cokroaminoto Palopo Jalan Lamaranginang, Kelurahan Batupasi, Kecamatan Wara Utara, Kota Palopo. Metode percobaan yang digunakan adalah Rancangan Acak Kelompok (RAK) yang terdiri dari 5 perlakuan dan 4 ulangan sehingga terdiri 20 unit percobaan. Masing-masing unit percobaan terdiri atas 2 unit tanaman sehingga terdapat 40 sampel tanaman. Parameter yang diamati adalah tinggi tanaman, umur berbunga, panjang akar, bobot polong dan jumlah biji. Hasil penelitian menunjukkan bahwa, pengaplikasian pupuk cair berbahan dasar limbah buah dan sayur memberikan pengaruh nyata terhadap pertumbuhan dan hasil tanaman kacang tanah. Konsentrasi pupuk cair limbah buah dan sayur yang efektif adalah P4 (250 mL. $\mathrm{L}^{-1}$ air), menghasilkan tinggi tanaman terbaik dengan nilai rata-rata $20,93 \mathrm{~cm}$, rata-rata umur berbunga terbaik 33 hari, rata-rata panjang akar terbaik $4,49 \mathrm{~cm}$ dan rata-rata bobot polong terbaik dengan

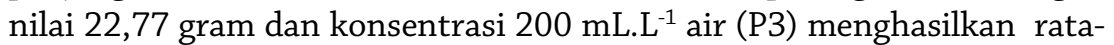
rata jumlah biji terbaik dengan nilai 340,25 biji. 


\section{PENDAHULUAN}

Kacang tanah merupakan salah satu komoditas pangan sumber protein dan minyak nabati yang bernilai ekonomi tinggi (Purba, 2012 dalam Swastika, 2015). Di Indonesia sebagian besar kacang tanah baru dimanfaatkan untuk makanan rumah tangga seperti: kacang rebus, kacang garing, kacang goreng, bumbu masakan, dan makanan ringan lainnya. Sebenarnya kacang tanah potensial untuk diolah dalam industri makanan menjadi berbagai produk makanan olahan seperti: aneka kue, susu nabati, tepung protein tinggi, es krim, dan minyak nabati (Santosa, 2010).

Produksi kacang tanah di Provinsi Sulawesi Selatan dalam kurun waktu 5 tahun berfluktuatif. Dapat diketahui bahwa produksi kacang tanah dari tahun 20142018 berturut-turut yakni, 34.464 ton, 19.024 ton, 29.403 ton, 16.169 ton, dan 19.152 ton (Statistik Pertanian, 2018). Hal ini menjadikan permintaan akan kacang tanah terus mengalami peningkatan. Semakin meningkatnya permintaan kacang tanah, maka produksi kacang tanah harus ditingkatkan. Salah satu cara meningkatkan produksi kacang tanah adalah dengan memanfaatkan alam sekitar dengan pemanfaatan limbah yang diolah menjadi pupuk organik.

Pupuk organik terdapat dalam bentuk padat dan cair. Kelebihan dari pupuk organik cair adalah unsur hara yang terdapat di dalamnya lebih mudah diserap oleh tanaman (Murbandono, 1995 dalam Rahmah, Izzati, \& Parman, 2014). Pupuk cair kebanyakan diaplikasikan melalui daun atau disebut sebagai pupuk cair foliar yang mengandung hara makro dan mikro esensial (N, P, K, S, Ca, $\mathrm{Mg}, \mathrm{B}, \mathrm{Mo}, \mathrm{Cu}, \mathrm{Fe}, \mathrm{Mn}$, dan bahan organik). Pupuk organik cair selain dapat memperbaiki sifat fisik, kimia, dan biologi tanah, juga membantu meningkatkan produksi tanaman, meningkatkan kualitas produk tanaman, mengurangi penggunaan pupuk anorganik dan sebagai alternatif pengganti pupuk kandang (Parman, 2007).

Produksi sayuran dan buah-buahan di Kota Palopo terbilang cukup besar, padahal buah dan sayuran yang tidak dimanfaatkan berkisar $20-30 \%$ dari bagian tanaman yang dimanfaatkan, sehingga ketersediaan limbahnya sangat berpotensi untuk dijadikan sebagai pembuatan pupuk. Purwendro dan
Nurhidayat (2006) menambahkan bahwa, bahan baku pupuk cair yang sangat bagus dari sampah organik yaitu bahan organik basah seperti sisa buah dan sayuran, selain mudah terdekomposisi, bahan ini juga kaya akan hara yang dibutuhkan oleh tanaman.

\section{BAHAN DAN METODE}

\section{Bahan}

Bahan yang digunakan dalam penelitian ini adalah limbah buah pisang, limbah jeruk, limbah sayur kacang panjang, kacang tunggak, kangkung, dan bayam yang diperoleh dari pasar yang berada di Kota Palopo, Sulawesi Selatan; benih kacang tanah Varietas Kelinci; air; molase; air cucian beras; EM4.

\section{Desain Penelitian}

Penelitian ini menggunakan Rancangan Acak Kelompok (RAK) yang terdiri dari 5 perlakuan dan 4 ulangan sehingga terdiri 20 unit percobaan. Masing-masing unit percobaan terdiri atas 2 unit tanaman, sehingga terdapat 40 sampel tanaman. Adapun perlakuannya yakni, (P0): Kontrol, (P1): $100 \mathrm{~mL} \cdot \mathrm{L}^{-1}$ air, (P2): 150 mL. $\mathrm{L}^{-1}$ air, (P3): $200 \mathrm{~mL} . \mathrm{L}^{-1}$ air, (P4): 250 $\mathrm{mL} . \mathrm{L}^{-1}$ air. Hasil yang memberikan pengaruh nyata selanjutnya diolah menggunakan uji lanjut BNJ taraf 5\%.

\section{Pembuatan Pupuk cair}

Pembuatan pupuk cair diawali dengan menyiapkan limbah buah dan sayuran sebanyak $2 \mathrm{~kg}$ dan dicincang halus kemudian tersebut dimasukkan kedalam ember, selanjutnya ditambahkan molasses dan air cucian beras dengan perbandingan 1:1, yakni masing $500 \mathrm{~mL}$, EM4 $200 \mathrm{~mL}$ dan ember diisi air sampai penuh, yaitu sebanyak $5 \mathrm{~L}$. Kemudian campuran bahan tersebut diaduk selama \pm 5 menit hingga semua bahan telah tercampur dan kemudian ember ditutup dan dilakukan fermentasi selama 2 minggu.

\section{Penanaman dan Aplikasi Pupuk Cair}

Penanaman dilakukan dengan cara membuat lubang sedalam $3 \mathrm{~cm}$. Benih kacang tanah ditanam sebanyak 2 butir pada tiap lubang tanam, kemudian ditutup dengan tanah. Adapun jarak antar tanaman $15 \times 15 \mathrm{~cm}$. Aplikasi pupuk cair dilakukan pada daun ketika tanaman berumur 2 minggu setelah tanam (MST) dan dilakukan pada waktu sore 
hari. Kacang tanah dipanen setelah berumur \pm 3 bulan setelah tanam.

\section{Pemanenan}

Panen kacang tanah bertujuan mengambil buah yang ada di dalam tanah. Ciri fisik kacang tanah yang sudah siap panen adalah batang mulai mengeras, daun mulai menguning dan sebagian mulai menggugurkan daun, polong diambil jika sudah terisi penuh dan keras serta warna polong sudah coklat kehitam-hitaman. Polong yang sudah tua biasanya sudah keras dan berwarna kecoklatan karena telah berisi penuh, sementara yang masih muda biasanya tidak keras dan berwarna putih muda.

\section{Parameter Pengamatan}

Parameter yang diamati dalam penelitian ini adalah tinggi tanaman, umur berbunga, panjang akar, bobot polong, dan jumlah biji.

\section{HASIL DAN PEMBAHASAN}

Berdasarkan penelitian yang dilakukan dan pengolahan data analisis sidik ragam, diperoleh hasil yang sangat berpengaruh nyata terhadap parameter tinggi tanaman, umur berbunga, panjang akar, jumlah biji dan bobot polong. Hal ini dikarenakan mineralisasi pupuk cair berbahan dasar limbah buah dan sayur melepaskan unsur hara makro dan mikro sehingga ketersediaan hara dalam tanah meningkat. Peningkatan ketersediaan hara akan berpengaruh terhadap peningkatan serapan hara sehingga proses pertumbuhan juga meningkat.

\section{Tinggi Tanaman dan Panjang Akar}

Perlakuan terbaik pada parameter tinggi tanaman dan panjang akar ditunjukkan pada (P4) 250 mL.L-1 air. Kadarwati (2006) menyatakan bahwa nitrogen merupakan unsur hara makro yang paling banyak dibutuhkan tanaman dan unsur nitrogen sangat berperan dalam fase vegetatif tanaman. Setyamijaya dalam Rahmah dkk. (2014) menambahkan bahwa peningkatan tinggi tanaman terjadi karena unsur hara nitrogen mampu memacu pertumbuhan meristem apikal sehingga tanaman bertambah panjang. Semakin tinggi konsentrasi pupuk yang diberikan maka akan lebih cepat meningkatkan perkembangan organ seperti akar, sehingga tanaman dapat menyerap lebih banyak hara dan air yang

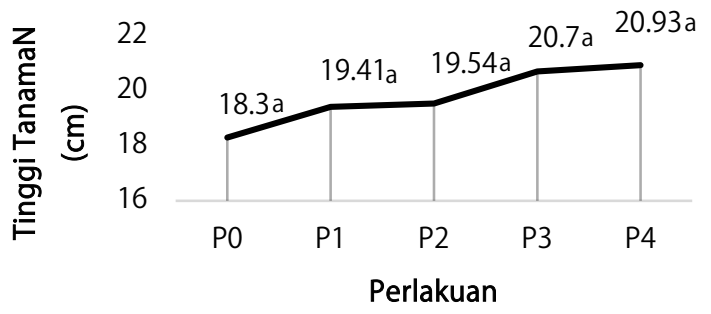

Gbr. 1. Rerata tinggi tanaman kacang tanah setelah aplikasi pupuk cair limbah buah dan sayur

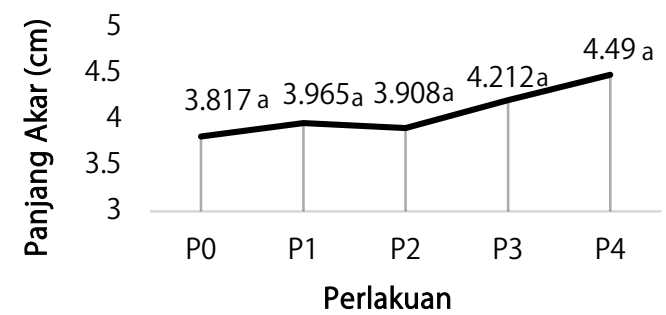

Gbr. 2. Rerata panjang akar kacang tanah setelah aplikasi pupuk cair limbah buah dan sayur

selanjutnya akan mempengaruhi organ lainnya. Selain itu mampu merangsang pertumbuhan secara keseluruhan khususnya cabang, dan daun, pembentukan zat hijau daun yang sangat berguna dalam proses fotosintesis. Apabila fotosintesis meningkat, maka meningkat pula sintesis karbohidrat (Sarief dalam Hayanti, Yuliani, \& Fitrihidayati, 2014). Karbohidrat ini diperlukan dalam pembelahan sel, pembesaran sel dan pembentukan jaringan untuk perkembangan batang, daun dan akar (pertumbuhan vegetatif) (Gardner, Pearce, \& Mitchell, 1991). Pemberian nitrogen yang tepat akan meningkatkan pertumbuhan tanaman, maka meningkat pula metabolisme tanaman sehingga pembentukan protein, karbohidrat dan pati tidak terhambat. Akibatnya pertumbuhan dan produksi tanaman meningkat.

\section{Bobot Polong dan Umur Berbunga}

Bobot polong dan umur berbunga terbaik ditunjukkan pada (P4), hal ini dikarenakan pembentukan polong isi penuh berkaitan dengan waktu pembungaan. Tanaman yang cepat berbunga, ginofora akan cepat memasuki tanah sehingga akan cepat terbentuk polong. Salisbury dan Ross (1995), mengemukakan bahwa perkembangan buah ditentukan oleh proses perkecambahan serbuk sari pada putik atau penyerbukan yang diikuti oleh 
pembuahan. Selain itu, adanya unsur hara $\mathrm{P}$ yang cukup tersedia pada pemberian pupuk cair limbah buah dan sayuran yang berperan dalam pembentukan bunga. Fosfor merupakan unsur yang sangat penting untuk pertumbuhan tanaman, memegang peranan dalam mekanisme transfer energi dan proses reproduksi. Kekurangan fosfor akan menekan kecepatan pertumbuhan yang akan berdampak pada penurunan produksi, serta kualitas buah dan biji. Fosfor memegang peranan penting dalam proses fotosintesis, membantu proses penguraian karbohidrat dan sintesis berbagai senyawa organik serta perpindahan energi antar sel. Kekurangannya akan mengakibatkan perakaran dan perkembangan daun lambat serta jumlah percabangan sedikit sehingga tanaman akan tetap kurus dan kerdil, fosfor dapat berpengaruh menguntungkan pada pembelahan sel dan pembentukan lemak serta albumin, pembungaan dan pembuahan, termasuk proses pembentukan biji, selain itu dalam pertumbuhan dan metabolisme tanaman, fosfor berfungsi sebagai penyusun ADP dan ATP. ATP diperlukan sebagai energi dalam proses respirasi. Dari hasil repirasi akan dihasilkan giberelin yang memacu proses pembentukan bunga.

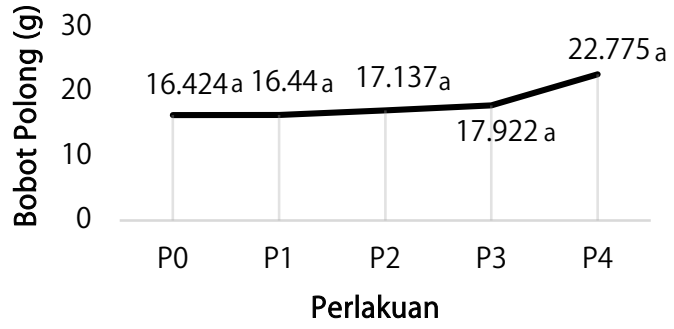

Gbr. 3. Rerata bobot polong kacang tanah setelah aplikasi pupuk cair limbah buah dan sayur

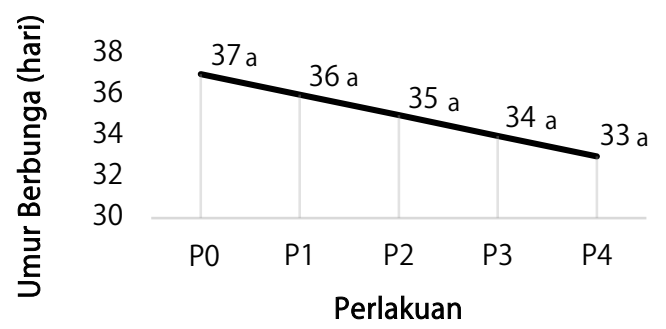

Gbr. 4. Rerata umur berbunga kacang tanah setelah aplikasi pupuk cair limbah buah dan sayur

Proses pembentukan biji pada kacang tanah dipengaruhi ketersediaan unsur $\mathrm{N}, \mathrm{P}$, dan $\mathrm{K}$ yang sangat penting dalam proses pembentukan polong dan pengisian biji.
Ispandi dan Munip (2004) menyatakan bahwa unsur kalium sangat memacu dalam peningkatan pembentukan polong dan pengisian biji. Selain itu, Hopkins dan Hüner (2009) menambahkan bahwa unsur $\mathrm{K}$ membantu pengangkutan gula dari daun ke buah atau umbi.

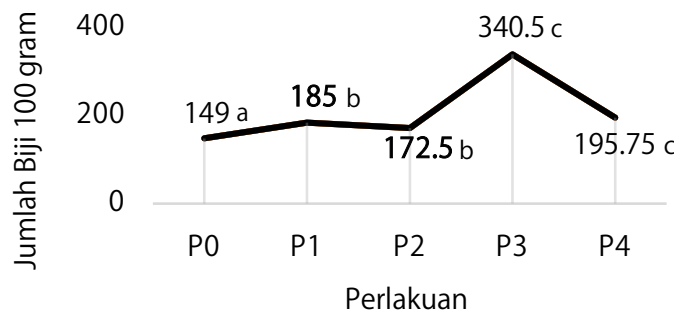

Gbr. 5. Rerata jumlah biji kacang tanah setelah aplikasi pupuk cair limbah buah dan sayur

\section{KESIMPULAN}

Pengaplikasian pupuk cair berbahan dasar limbah buah dan sayur memberikan pengaruh nyata terhadap pertumbuhan dan hasil tanaman kacang tanah. Konsentrasi pupuk cair limbah buah dan sayur yang efektif adalah $250 \mathrm{~mL} \cdot \mathrm{L}^{-1}$ air (P4) yang menghasilkan tinggi tanaman terbaik dengan nilai rata-rata 20,93 $\mathrm{cm}$, umur berbunga terbaik 33 hari, rata-rata panjang akar terbaik $4,49 \mathrm{~cm}$ dan rata-rata bobot polong terbaik dengan nilai 22,77 gram, sedangkan konsentrasi $200 \mathrm{~mL} \cdot \mathrm{L}^{-1}$ air (P3) menghasilkan rata-rata jumlah biji terbaik dengan nilai 340,25 biji.

\section{DAFTAR PUSTAKA}

Gardner, F. P., Pearce, R. B., \& Mitchell, R. L. (1991). Fisiologi Tanaman Budidaya (Alih bahasa oleh H. Susilo \& Subyanto). Jakarta: UI Press.

Hayanti, E. D. N., Yuliani, \& Fitrihidayati, H. (2014). Penggunaan kompos kotoran kelelawar (Guano) untuk meningkatkan pertumbuhan tanaman kacang tanah (Arachis hypogaea). LenteraBio, 3(1), 7-11.

Hopkins, W. G., \& Hüner, N. P. A. 2009. Introduction to Plant Physiology (4th ed.). London: John Wiley \& Sons Inc.

Ispandi, A., \& Munip, A. (2004). Efektivitas pupuk $\mathrm{PK}$ dan frekuensi pemberian pupuk $\mathrm{K}$ dalam meningkatkan serapan hara dan produksi kacang tanah di lahan kering alfisol. Ilmu Pertanian, 11(2), 11-24.

Kadarwati, F. T. (2006). Pemupukan rasional 
dalam upaya peningkatan produktivitas kapas. Perpektif, 5(2), 59-70.

Statistik Pertanian. (2018). Produksi kacang tanah menurut provinsi 2014-2018. Retrived Juli, 2019,

http://epublikasi.setjen.pertanian.go.id/ep ublikasi/StatistikPertanian/2018/Statistik \%20Pertanian\%202018/files/assets/basichtml/page150.html

Parman, S. (2007). Pengaruh pemberian pupuk organik cair terhadap pertumbuhan dan produksi kentang (Solanum tuberosum L.) Buletin Anatomi dan Fisiologi, 15(2), 21-31.

Purwendro, S., \& Nurhidayat. (2006). Mengolah Sampah untuk Pupuk Pestisida Organik. Depok: Penebar Swadaya.

Rahmah, A., Izzati, M., \& Parman, S. (2014). Pengaruh pupuk organik cair berbahan dasar limbah sawi putih (Brassica chinensis L.) terhadap pertumbuhan tanaman jagung manis (Zea mays L. var Saccharata). Buletin Anatomi dan Fisiologi, 12(1), 65-71.

Salisbury, F. B., \& Ross, C. W. (1995). Fisiologi Tumbuhan (Jilid 3, Diterjemahkan oleh Diah R. Lukman \& Sumaryono). Bandung: Penerbit ITB.

Santosa, B. A. S. (2010). Inovasi teknologi defatting: peluang peningkatan diversifikasi produk kacang tanah dalam industri pertanian. Pengembangan Inovasi Pertanian, 3(3), 199-211.

Swastika, D. K. S. Ekonomi kacang tanah di Indonesia. Retrieved June 2019, from http://balitkabi.litbang.pertanian.go.id/wp -content/uploads/2015/06/1.\%20_OK_ dew a\%20_1-17_.pdf 